\title{
Faktor -Faktor yang Mempengaruhi Personal Branding dalam Membangun Citra dan Popularitas dalam Media Sosial
}

\author{
Desy Tri Anggarini* \\ Universitas Bina Sarana Informatika Jakarta, Indonesia \\ Jl. Proklamasi A No.7, RW.8, Mekar Jaya, Kec. Sukmajaya, Kota Depok, Jawa Barat 16411 \\ * desy.dra@bsi.ac.id
}

\begin{abstract}
Abstrak- Personal brand is a collective representation of how a person is perceived by the public, in social media. Personal branding is promoting the strengths and uniqueness of individuals for a target audience. Personal branding has become an effective way of communication between a person and their respective publics, distinguishing them from their competitors based on their uniqueness and distinct values. The purpose of this research is a personal branding concept to become an attribute to be more professional, be able to create, promote, and develop themselves through social media. Personal branding a very easy and practical way through social media can help, open doors for personal branding and can easily find out, and get success and new career opportunities, partnerships and audiences for their work. The result of the research is that social media plays a very important role of creation of a personal brand. The better access online tools like Facebook, LinkedIn, Twitter and Pinterest and more. All media online profiles including your username, password and/or when you started recording. Pay attention to the types of posts you share through these profiles, for example on LinkedIn, share information about portfolio experts, who your people meet with each profile. on Facebook, friends, family and partners. Create content on your profile with the administration of the interpersonal organization you use. This research method is a qualitative research with a descriptive approach, because considering that personal branding research through social media is an application carried out by someone personally. The implications of the research are getting easier to get a better job, easy to get relevant company contacts and clients, industry recognition, also getting more opportunities and creating better growth of work.
\end{abstract}

Keywords: Keywords: Identity, Social Media, Personal branding, Publication, Reputation, Human resources.

Abstrak- Personal brand adalah representasi kolektif tentang bagaimana seseorang dirasakan oleh publik, dalam media sosial. Personal brand adalah mempromosikan kekuatan dan keunikan individu untuk suatu target audiens. Personal branding telah menjadi cara komunikasi yang efektif antara seseorang dan publiknya masing-masing, membedakan mereka dari pesaing mereka berdasarkan keunikan dan nilai-nilai yang berbeda. Tujuan dari penelitian ini adalah suatu konsep personal branding menjadi atribut untuk lebih profesional, sehingga mampu membuat, mempromosikan, dan mengembangkan diri melalui media sosial. Personal branding suatu cara yang sangat mudah dan praktis melalui media sosial dapat membantu, membuka pintu untuk personal branding serta dapat dengan mudah mengetahui, dan memperoleh kesuksesan serta peluang karir baru, kemitraan dan audiens untuk pekerjaan mereka. Hasil dari penelitian adalah media sosial memainkan peran yang sangat penting dalam penciptaan merek pribadi. Akses yang baik dengan bantuan alat online seperti Facebook, LinkedIn, Twitter dan Pinterest dan lainnya. Semua profil media online termasuk nama pengguna, kata sandi, dan/atau kapan Anda memulai rekaman. Memperhatikan jenis pos yang Anda bagikan melalui ini profil, misalnya di LinkedIn, berbagi informasi tentang pakar portofolio, siapa pertemuan orang-orang Anda dengan setiap profil. di Facebook, teman, keluarga, dan mitra. Membuat konten di profil Anda dengan administrasi organisasi interpersonal yang Anda gunakan. Metode peneliti ini adalah penelitian kualitatif dengan pendekatan deskriptif, karena mengingat penelitian personal branding melalui media sosial adalah merupakan penerapan yang dilakukan oleh seseorang secara personal . Implikasi dalam penelitian adalah mendapatkan kemudahan memperoleh pekerjaan yang lebih baik, mudah memperoleh kontak dan klien perusahaan yang relevan, adanya pengakuan industri, juga memperoleh lebih banyak peluang serta terciptanya pertumbuhan yang lebih baik

Kata Kunci: Identitas, Media sosial, Personal branding, Publikasi, Reputasi, Sumber daya manusia.

\section{PENDAHULUAN}

Masyarakat Indonesia merupakan penduduk yang sebagian besar aktif dalam media sosial. Namun media sosial saat ini belum banyak digunakan untuk personal branding oleh seseorang di Indonesia. Padahal media sosial membuka peluang besar untuk personal brand sehingga dapat memberikan hal yang positif bagi perkembangan profesi di kemudian hari. Perkembangan teknologi saat ini membuat personal brand melalui media sosial semakin penting karena
Identitas dari individu dapat dibentuk secara keseluruhan atau komprehensif simultan dalam ruang virtual dan realitas masyarakat umumnya [1].

Pertumbuhan pengguna media sosial adalah perubahan di mana media sosial awalnya hanya sebagai media untuk berinteraksi satu sama lain namun berubah menjadi promosi barang atau jasa, juga menjadi media marketing. Pemasaran diri disebut sebagai personal branding, personal branding adalah sekumpulan keterampilan, ide, sistem kepercayaan, 
juga nilai yang dianggap menarik oleh orang lain. Banyak orang yang sukses dan berhasil dalam melakukan personal branding di media sosial namun ada juga yang gagal namun individu yang sukses adalah memiliki kekuatan yang sangat kekuatan, seperti merek (branding) yang tidak hanya dianut oleh produk namun juga identitas telah ada dan sudah melekat pada diri pribadi masing-masing [2].

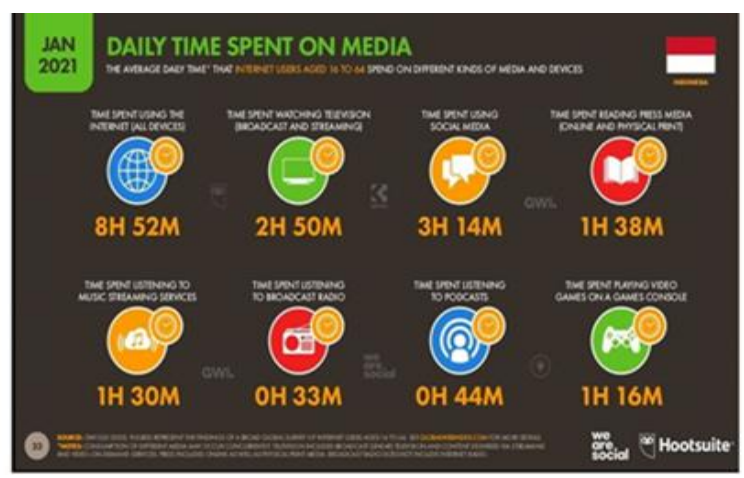

Gambar 1. Daily Time Spent on Media [3]

Pada era Pandemi Covid-19 banyak orang melakukan sosial distancing, sehingga masyarakat lebih sering berada dirumah mengunakan internet dan menghabiskan waktu di sosial media. Di Indonesia rata rata menghabiskan waktu untuk pemakaian media sosial selama tiga jam 14 menit sehari menggunakan internet.

Jumlah populasi penduduk Indonesia sebanyak 274,9 juta jiwa, yang aktif dalam menggunakan media sosial mencapai 61,8 persen atau sebanyak 170 juta jiwa, angka ini merupakan market share yang cukup besar, sehingga dapat digunakan dalam media komunikasi yang cukup efektif. Negara Indonesia termasuk dalam 10 besar negara yang menggunakan media sosial terbesar di dunia, sejumlah 170 juta jiwa menggunakan phone selular atau smartphone dan tablet untuk mengakse media sosial dengan penetrasi 99 persen.

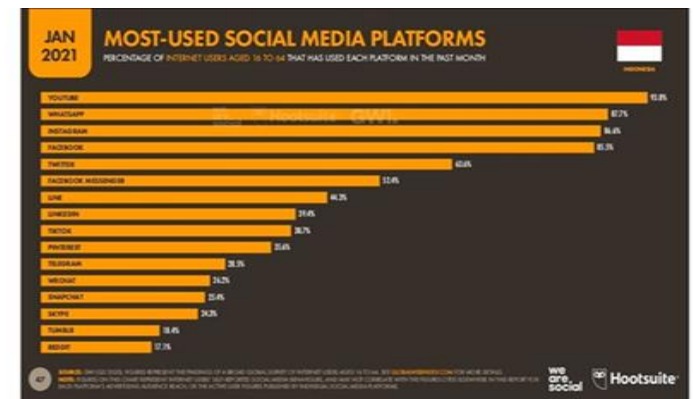

Gambar 2. Most-Used Social Media Platform [3]
Dalam rentang waktu dalam sehari yang dihabiskan untuk mengakses internet adalah 8 jam 52 menit. Aplikasi apa saja yang popular di Indonesia secara berurutan dalam posisi teratas yaitu YouTube, WhatsApp, Instagram, Facebook, lalu Twitter. Sedangkan aplikasi social media yang sering digunakan dengan basis androit adalah WhatsApp, Facebook, Instagram, TikTok, lalu Twitter.

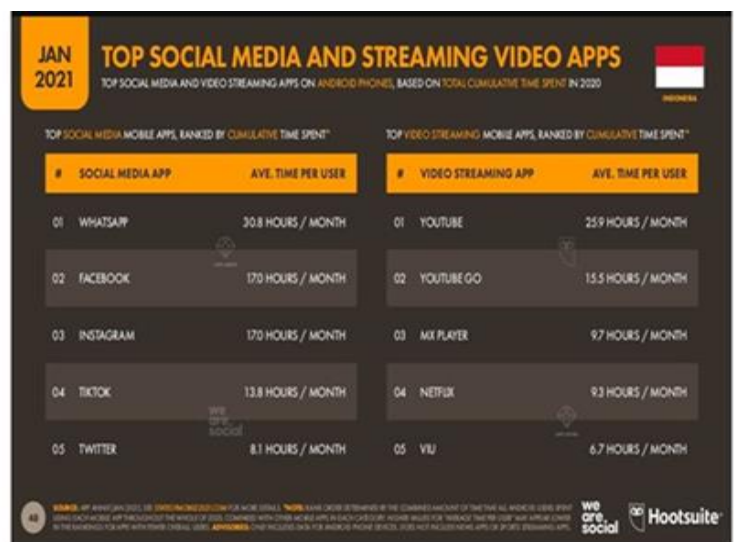

Gambar 3. Top Social Media and Streaming Video Apps [3]

Sejak konsep personal branding menjadi atribut untuk lebih profesional, sehingga mampu membuat, mempromosikan, dan mengembangkan diri melalui media sosial. Hal ini merupakan suatu jalan yang sangat mudah dan praktis melalui media sosial dapat membantu, membuka pintu untuk personal branding serta dapat dengan mudah mengetahui cara menggunakan serta memperoleh kesuksesan serta peluang karir baru, kemitraan dan audiens untuk pekerjaan mereka [4].

Personal brand dilakukan dengan berbagai cara yaitu (1) Menampilkan foto profil dan kegiatan yang positif, menggunakan objek foto juga aktivitas yang positif sesuai dengan objek, (2) Individu harus memiliki hal citra diri pribadi masing - masing atau individu, (3) Sesorang harus menampilka suatu hal yang konsisten dan berulang, (4) Perlu menggunakan berbagai ragam media sosial sesuai sehingga menjadi tercapai fungsi dan tujuan dari citra diri [1].

Digital platform sebagai pengguna utama media sosial, media sosial memberikan wawasan kritis tentang praktik personal branding yang muncul di media sosial media, yang dikenal sebagai "Audiens masa depan" diperkenalkan untuk menggambarkan bagaimana individu memproyeksikan personal branding yang dikurasi untuk semua audiens yang tidak diketahui dan tidak terduga di masa depan, dana merupakan identitas profesional.Hal itu terjadi karena 
ketidakpastian tempat kerja, manajer media sosial mewujudkan mentalitas "selalu di pasar kerja", yang merupakan pendorong personal branding dalam upaya mereka untuk mendapatkan atau mempertahankan pekerjaan [5].

Sementara personal branding sebagian besar dibahas oleh para profesional industri, ada kebutuhan tentang personal branding yang mengkaji bagaimana berbagai kelompok karyawan mengalami personal branding. Hal ini menganalisis bagaimana orang bekerja di media sosial dengan branding identitas mereka dan bagaimana personal branding mereka digunakan untuk memasarkan diri mereka sendiri untuk mendapatkan dan mempertahankan pekerjaan. Perkembangan dari "audiens masa depan" dan "pasar tenaga kerja" dapat digunakan untuk memahami profesi dan pengalaman personal branding lainnya [5].

Personal Branding adalah tindakan individu mempromosikan diri mereka sendiri, juga merupakan suatu merek atau personal branding. Sementara diri masa lalu metode manajemen perbaikan adalah tentang perubahan diri, ide personal-branding merekomendasikan bahwa prestasi berasal dari selfbundling [6].

Semakin banyak penggunaan media internet di Indonesia dan berbagai aplikasi yang ada, semakin banyak pengunaan media sosial, namun sangat disayangkan penggunaan media sosial masih banyak digunakan untuk sekedar hiburan atau komunikasi saja. Namun belum banyak yang menggunakan sebagai alat untuk personal branding. Hanya sebagian kecil yang menggunakan untuk memposisikan diri sebagai brand. Personal branding tidak harus seorang public figure atau artis yang mudah membuat suatu visual foto, gambar, video, atau kegiatan yang relevan dalam suatu profesi, namun seseorang professional muda yang akan membangun karir bisa membuat personal brand di berbagai media sosial.

Hal ini mengangkat penelitian mengenai Faktor Faktor yang Mempengaruhi Personal Branding dalam Membangun Citra dan Popularitas dalam Media Sosial. Tujuannya adalah membuat konsep personal branding menjadi atribut untuk lebih professional sehingga dapat mempromosikan diri, dan mengembangkan personal melalui media sosial.

\section{KAJIAN PUSTAKA}

Personal branding pada dasarnya adalah berkelanjutan prosedur pengaturan citra atau gambaran yang direkomendasikan juga kesan individu terhadap orang lain. Personal branding secara teratur termasuk penggunaan nama seseorang untuk item yang berbeda, sebagai contoh orang penting VIP yang digunakan Donald Trump namanya terus berlanjut secara luas di strukturnya dan di barang yang dia tanggung. Pencitraan merek telah mencapai tingkat kewajiban dasar dalam pencarian di internet. Perkembangan dari dunia maya membuat perlunya pengawasan online. Meskipun secara eksplisit virtual, sosial jaringan dan karakter online dapat memengaruhi suatu realitas. Disini individu perlu menggambarkan dan diskripsikan diri mereka sebagai jalur tertentu ke grup teman mereka, juga mungkin bekerja untuk pertahankan gambaran tertentu di jaringan online mereka lokal. Oleh karena itu, jaringan online memberdayakan pembuatan kepribadian online yang mungkin tidak sepenuhnya konsisten dengan diri sejati [6].

Di antara pencari pekerjaan, ini mendorong bergeser jauh dari tindakan menyajikan resume sebagai aspek prosedur aplikasi tanggung jawab mereka untuk perabotan bisnis potensial dengan akses ke berbagai merek pribadi sumber daya. Sumber daya tersebut bertanggung jawab untuk memasukkan resume, koneksi ke LinkedIn yang diawasi dengan susah payah profil dan situs pribadi, konfirmasi artikel yang sebarkan pemikiran unik di situs web industri dan bukti memiliki web mengambil setelah. Upaya seperti itu memberikan pekerjaan pencari peluang yang lebih baik untuk dilihat oleh calon bisnis [6].

Personal branding tidak hanya untuk nama besar atau yang ada di bagian perusahaan. Sebagai seorang analis, menerima prosedur dan praktik yang dibuat di perguruan tinggi bisnis untuk membuat merek Anda sendiri dapat menjadi alat yang intens untuk menampilkan diri [6].

Setiap orang dicap secara individual: seseorang mungkin tidak menyadari, mengakui, merangkul, atau mengelola merek mereka, tetapi tentu saja ada. Di Amerika Utara dan di berbagai negara industri negara, pentingnya merek pribadi telah muncul sebagai topik yang berulang dalam wacana populer dan akademisi selama sepuluh tahun terakhir. Personal Branding didefinisikan sebagai proses mengembangkan, memanfaatkan, dan mengklasifikasikan informasi pribadi dan memberikan narasi yang komprehensif bagi orang lain untuk dengan mudah memahami seseorang identitas sering menggunakan media social [5].

Manajer media sosial berada di garis depan personal branding dan menawarkan perspektif unik untuk memahami strategi personal branding bahwa mereka secara pribadi mengalami dan menyaksikan secara profesional di media social [5].

\section{(†) ()}


Mempertimbangkan bahwa para profesional media sosial ini terlibat dengan komunitas target dan pelanggan mereka menggunakan media sosial, mereka ada di persimpangan pengguna media sosial, media sosial konsumen, profesional media sosial, dan media sosial influencer. Manajer media sosial mengalami tekanan dari media sosial secara langsung, dan mereka juga merupakan bagian dari muncul profesi berbasis media social [5]. Personal branding sosial manajer media sebagai praktik profesional dengan menghubungkan masalah personal branding dengan munculnya profesi baru: manajemen media sosial. Manajer media sosial adalah Social bertanggung jawab untuk mengelola dan menjalankan merek organisasi dan kehadiran di berbagai media sosial dan platform digital [5].

Manajer media sosial sangat menyadari perlunya personal branding untuk kesuksesan karir. Personal branding mengembangkan dan menjalankan strategi sosial ini di garis depan digital; mereka adalah pencipta dan produser digital yang sangat terlibat dengan manajemen media sosial dan personifikasi individu cerdas digital memimpin tren media sosial. Sebagai pengguna utama media sosial, pengelola media sosial menyediakan wawasan kritis tentang praktik branding pribadi yang muncul di media social [5].

Sementara personal branding sebagian besar dibahas oleh industri profesional, ada kebutuhan untuk penelitian empiris tentang personal branding yang meneliti bagaimana pengalaman berbagai profesi personal branding. Kesenjangan ini dengan menganalisis bagaimana orang-orang yang bekerja di media sosial mencap identitas mereka sendiri dan bagaimana personal branding digunakan untuk memasarkan diri mereka sendiri untuk mendapatkan dan mempertahankan pekerjaan. Secara khusus, bagaimana media sosial manajer membangun merek pribadi dan mempresentasi diri di media social [5].

Personal Branding adalah istilah dari tanda, lambang atau rancangan, atau gabungan dari semuanya yang memungkinkan orang untuk mengidentifikasi barang. dan jasa keluar dari pesaing. Personal Branding adalah cara sesuatu yang ada dalam diri Anda yang kemudian menjadi khas dan ada efek menjual personal diri, seperti Anda membawa pesan diri dan ini merupakan taktik pemasaran pribadi. Personal Branding adalah sesuatu tentang bagaimana mengendalikan penilaian seseorang terhadap Anda sebelum bertemu secra langsung dengan Anda, tetapi mungkin mereka melihat kegiatan anda di media sosial. Jadi personal Branding adalah sesuatu hal menarik dari seseorang, yang kemudian membedakan dengan orang lain sehingga menjadi lebih dan membuat seseorang berdiri keluar dari orang lain. Personal branding terdiri dari empat elemen, seperti atribut, keuntungan yang dijanjikan, nilai kepribadian, personal branding digunakan sebagai alat untuk membuat opini orang lain terhadap audience [6].

\section{METODE PENELITIAN}

Metode penelitian Faktor -Faktor yang Mempengaruhi Personal Branding dalam Membangun Citra dan Popularitas dalam Media Sosial merupakan jenis penelitian kualitatif metode deskriptif, karena dalam penelitian personal branding melalui media massa adalah merupakan implikasi yang dilakukan oleh seseorang secara personal di media sosial [7]. Data penelitian ini pmenggunakan ada studi kepustakaan berupa buku, literature, jurnal, juga artikel mengenai Personal Branding Upaya Meningkatan Popularitas dalam Media Sosial [8].

Penelitian ini menggunakan analisis dengan pendekatan kualitatif. Analisa kualitatif ini adalah suatu pengertian analisis didasarkan pada data diperoleh melalui studi lapangan maupun studi pustaka. Hal ini menganalisis data tidak hanya perhitungan kuantitatif, tetapi lebih dari menghubungkan informasi, fakta, data. Data diperoleh kemudian dianalisis sehingga deskripsi dan gambaran dari suatu permasalahan penelitian [7]

\section{HASIL DAN PEMBAHASAN}

Mendefinisikan personal branding, mirip dengan merek komersial, Personal brand adalah representasi kolektif tentang bagaimana seseorang dirasakan oleh public. Personal brand mempromosikan kekuatan dan keunikan individu untuk suatu audiens target. Personal branding adalah suatu kalan dan cara dalam komunikasi efektif antara seseorang dan audiencenya masing-masing, dan yang membedakan mereka dari pesaing adalaha berdasarkan keunikan dan nilai masing-masing [6].

Personal branding, seseorang dapat membangun diri mereka sendiri di luar resume dan mereka sebagai individu dan bagaimana mereka dapat menjadi aset bagi berbagai perusahaan. "Selfbranding adalah tentang memikirkan (diri sendiri) sebagai merek produk yang dapat dilihat strategis dan kreatif dalam pasar yang kompetitif untuk memberikan nilai maksimal bagi (individu) dan perusahaan" [6].

Personal branding melampaui dunia maya untuk memasukkan representasi dari pribadi sendiri. 
"Personal Branding, memiliki merek pribadi yang kuat adalah tentang bagaimana memproyeksikan 'pribadi' yang kuat dan konsisten pada citra merek untuk dirinya melalui cara mereka berbicara, cara mereka berperilaku, cara berbicara, berpakaian, juga penampilan yang terlihat kemudian mengendalikan visibilitas mengelola personal pribadi sendiri". Personal branding mencakup representasi dari kepribadian melalui berbagai media. [6].

Personal branding adalah suatu kesatuan dimana individu dan profesi mereka dipisahkan sebagai merek, idenya mengusulkan bahwa pencapaian berasal dari self-bundling. Keuntungan yang berhubungan antara individu namun tidak terbatas pada penampilan dan pembelajaran individu yang mendorong kesan permanen yang menarik untuk dilihat [6].

Personal Branding berasal dari kata personal yang artinya pribadi, kemudian brandin memmilki arti sebuah brand atau merek. Jadi personal branding yaitu aktivitas yang dilakukan oleh seseorang dalam membentuk karakter pribadi di media sosial. Brand/ merek didefinisikan sebagai persepsi yang dimiliki yan dalam berbagai pengalaman terhadap produk tersebut. Apabila didefinisi dan diaplikasikan dalam konteks personal, personal brand adalah persepsi atau emosi yang dimiliki oleh orang lain terhadap diri personal seseorang yang mendefinisikan secara keseluruhan pengalaman dalam relasi antarpersonal tersebut [9].

Personal branding didasarkan atas nilai-nilai kehidupan dan memiliki relevansi tinggi terhadap siapa sesungguhnya diri seseorang. Personal branding menjadi merek atau brand pribadi seseorang, yang menempel di benak orang lain pada saat berpikir tentang diri orang tersebut, dan membuat seseorang unik dan berbeda dengan orang lain, terdapat 3 (tiga) dimensi utama pembentuk personal branding, yaitu: (a) Kompetensi atau kemampuan individu, (b) Gaya atau style personal, dan (c) Standar personal seseorang [5].

Konsep "pemosisian pribadi" telah mendapatkan popularitas sejak Ries dan Trout memperkenalkan ide tersebut pada tahun 1981. Mereka menggunakan pemosisian pribadi untuk merujuk pada pakaian yang dikenakan seseorang, apa yang tidak dan kata-kata yang digunakan seseorang, tetapi penulis tidak memperluas syarat.
Lebih dari tiga dekade kemudian, personal branding para ahli di industri menyajikan argumen yang sama dengan kekuatan baru dan fokus pada media sosial sebagai lokus merek pribadi [9].

Dalam literatur ilmiah, ada tumpang tindih yang sangat besar dalam penggunaan istilah "merek manusia" dan "merek pribadi", sebagai istilah sering digunakan secara bergantian. Dengan lebih dari 100 diterbitkan makalah tentang personal branding, area ilmiah terfragmentasi dengan beberapa definisi yang berbeda dan konseptual yang tidak tepat batasan dengan branding manusia yang terkait erat konsep untuk personal branding. Personal Branding sebelumnya telah mengacu pada "setiap persona terkenal yang menjadi subjek dari upaya komunikasi pemasaran" [5].

Namun, beberapa penelitian mencoba merangkul lebih inklusif definisi sebagai persona yang terkenal atau muncul. Sebagai titik diferensiasi, merek personal kadang-kadang digunakan untuk merujuk pada selebriti tradisional (seperti atlet terkenal atau a musisi), sedangkan merek pribadi dapat digunakan untuk menggambarkan mereka yang tidak terkenal seperti selebriti atau yang lebih amatir di media social [5].

Sebagian besar strategi personal branding adalah ditargetkan pada para profesional yang ingin mengembangkan yang diinginkan identitas, tetapi praktiknya telah turun ke bawah karyawan hierarki untuk juga memasukkan orang-orang muda yang ingin memposisikan diri mereka sendiri untuk pekerjaan ditingkat pemula [5].

\section{A. Pentingnya Personal Branding}

Personal branding adalah prosedur dimana individu dan profesi mereka dipisahkan sebagai merek. Idenya mengusulkan bahwa pencapaian berasal dari self-bundling. Keuntungan yang berhubungan dengan individu atau individu tertentu Termasuk namun tidak terbatas pada penampilan dan pembelajaran individu yang mendorong kesan permanen yang menarik untuk dilihat. Istilah ini diperkirakan pertama kali digunakan dan dibicarakan sebagai bagian dari artikel tahun 1997 oleh Tom Peters. Sebagian besar eksplorasi merek hingga saat ini baru saja memeriksa merek dari sudut pandang tanpa jiwa; yaitu merek bukanlah makhluk hidup. Dengan dan oleh merek pribadi berkembang [6]. 
Membangun merek pribadi yang dapat dikenali membuka peluang profesional. Menciptakan visi untuk masa depan Anda dan menerapkan visi tersebut dapat mengarah pada:

1. Pekerjaan yang lebih baik

2. Kontak dan klien yang lebih baik untuk perusahaan Anda

3. Pengakuan industri

4. Lebih Banyak Peluang

5. Pertumbuhan Lebih Baik

Ada $3 \mathrm{C}$ dalam membangun dan mengelola reputasi Anda dan menciptakan Personal Brand [6].

1. Kredibilitas - Anda berdiri di atas integritas Anda

2. Konsistensi - Selalu berikan nilai

3. Kejelasan - Tujuan dan maknanya jelas

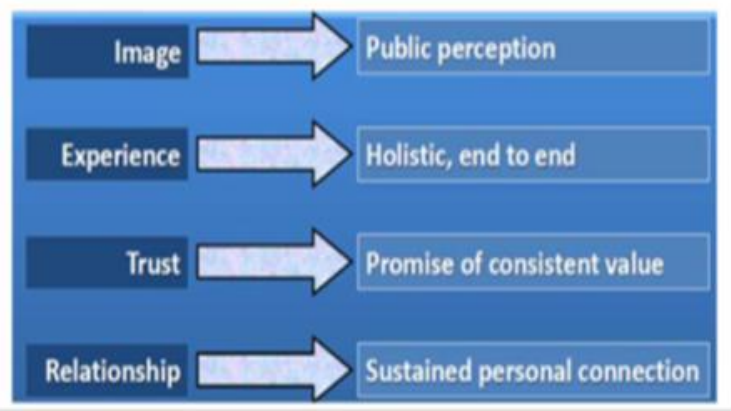

Gambar 4. Paparan Personal Branding

Membangun personal branding menjamin bahwa sebagai individu tidak tertinggal dalam proses pilihan pekerjaan dan bahwa mereka membangun keunggulan yang memposisikan mereka untuk peluang profesi yang pantas mereka dapatkan. Dengan posisi terbatas yang tersedia di pasar kerja saat ini, memiliki merek pribadi yang kuat adalah hal yang dapat membuka banyak jalan masuk untuk berbagai lowongan pekerjaan. Personal branding telah menjadi sudut penting bagi pelamar dalam mencari pekerjaan. Sementara banyak organisasi memanfaatkan peluang indeks web dan jaringan online sebagai alat pendaftaran untuk perwakilan masa depan, branding pribadi telah menjadi bagian penting dari proses perekrutan. "Perangkat online telah memungkinkan personal branding menjadi tugas promosi penting bagi individu biasa. Alasan personal branding adalah bahwa setiap orang memiliki kemampuan untuk menjadi merek mereka sendiri dan pekerjaan utama pria adalah menjadi pengiklan mereka sendiri," [10]. Mempertimbangkan ide ini, pencari kerja memiliki kesempatan untuk mencap diri mereka ke dalam apa pun yang mereka cari, panjangnya sesuai dengan kelompok minat yang mereka inginkan. Salah satu bagian terpenting dalam membangun merek pribadi adalah memisahkan antara kata-kata penting dalam rentang merek. Seperti yang ditunjukkan oleh [10], langkah awal dimulai dengan membangun karakter merek dan menyampaikannya melalui penempatan merek ke kelompok sasaran tertentu. "Kepribadian merek dicirikan sebagai bagaimana pengiklan membutuhkan merek untuk dilihat". Penempatan merek memanfaatkan karakter merek tertentu untuk memisahkan individu dari pesaing yang berbeda di dalam kelompok minat yang mereka maksudkan dengan menyoroti kualitas penting dan bagian dari kepribadian merek. Citra merek kemudian dicatat sebagai kesan individu dari kumpulan orang-orang mereka. Tanggapan ini adalah "pada umumnya mengingat perilaku yang jelas, tidak" [6].

Dengan naiknya jaringan online saat ini, manajemen merek pribadi seseorang menjadi kurang menuntut. Banyak orang menggunakan outlet yang berbeda, misalnya, Facebook, Twitter, situs web pribadi, dan LinkedIn, untuk membuat dan mempertahankan merek mereka sendiri. Cara untuk mempertahankan personal brand yang efektif adalah dengan menjaga konsistensi brand di semua media. "Kejelasan serta konsistensi adalah penting untuk membuat merek (branding) yang menarik," [6].

\section{B. Media Sosial Untuk Personal Brand}

Media sosial memainkan peran yang sangat penting dalam penciptaan merek pribadi. Anda dapat memiliki akses yang baik dengan bantuan alat online seperti Facebook, LinkedIn, Twitter dan Pinterest dll

1. Mulai ikhtisar semua profil jaringan online Anda termasuk nama pengguna, kata sandi, dan/atau kapan Anda memulai rekaman.

2. Perhatikan jenis pos yang Anda bagikan melalui ini profil Misalnya di LinkedIn, berbagi informasi tentang pakar portofolio.

3. Perhatikan siapa pertemuan orang-orang Anda dengan setiap Profil, sebagai contoh di Facebook, teman, keluarga, dan mitra melihat posting saya.

4. Buat konten di profil Anda dengan administrasi organisasi interpersonal yang Anda gunakan. 


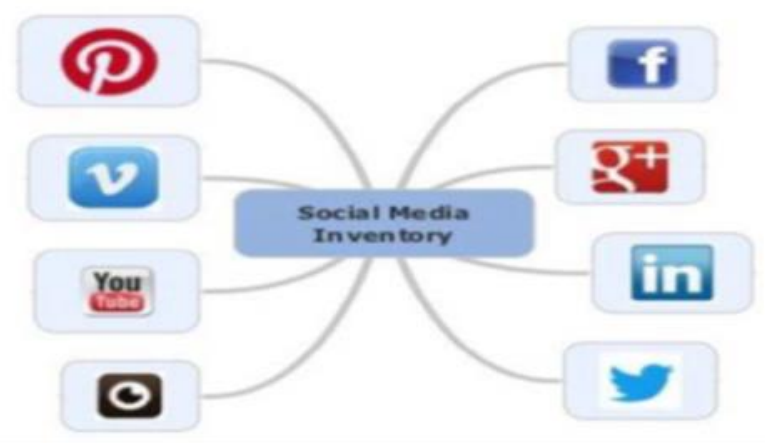

Gambar 5. Social Media Invetory untuk Personal Branding

Sebagai contoh LinkedIn harus memasukkan resume dan portofolio pribadi. Ada berbagai cara dan saluran yang melaluinya seseorang dapat membuat dan membangun merek pribadi mereka; salah satu membangun pribadi menjadi semakin penting selama beberapa tahun terakhir dalam jaringan online.

Personal branding, sangat penting untuk mengenali atribut yang membuat Anda istimewa dari pesaing Anda. Personal branding lebih memperhatikan oposisi mereka, pentingnya menjadi apa adanya, menjadi lebih natural. Ini adalah tentang mempengaruhi orang lain, dengan membuat personal branding yang baik.

Jaringan online mendorong personal branding melalui penciptaan karakter yang gambarnya bisa menjadi subjek. Hari ini kita hidup di dunia yang dipenuhi foto-foto dan memanfaatkan gambar secara lahiriah ini adalah suatu metode yang mampu untuk menyampaikan suatu pencitraaan seseorang.

Personal Branding adalah upaya yang diperlukan pengelolaan gambaran positif dari karakter seseorang. Personal branding ini bukan hanya dilihat dari audensi namun juga sebagai korespondensi perusahaan [6].

Ketika personal branding digunakan dengan kreativitas, perencanaan juga konsistensi, jadi dapat dipastikan bahwa personal branding akan membantu Anda dalam melakukan tiga hal :

1. Seseorang membangun nama dan memberi gambaran tentang karakter kepada orang lain

2. Dalam media sosial memberikan tindakan yang menarik dan jelas penjelasan,

3. Personal Barnding membantu dalam mengambil kendali klien. Ada tiga tingkat pengaruh di mana seseorang melakukan personal branding yaitu : Advokat dan Trendsetter yang di mana mereka mempengaruhi pemikiran tetapi tetap hadir dalam lingkup yang lebih besar yang seperti itu merek pribadi mereka tetap ada bahkan ketika tren itu berakhir.

4. Ikon - bukanlah sesuatu yang mudah dicapai tetapi cenderung berkembang secara organic [2].

Terdapat delapan hal dalam Konsep utama adalah acuan dalam membentuk pribadi seseorang merek

1. Hukum Spesialisasi, adalah personal branding yang hebat yang memiliki spesialisasi yang membuatnya berbeda baik dari segi kekuatan, keterampilan, atau pencapaian tertentu.

2. Hukum Kepemimpinan, pemimpin yang berkuasa dan Kredibilitas akan mampu memposisikan diri sebagai yang sempurna pemimpin yang dapat diandalkan oleh masyarakat.

3. Hukum Kepribadian, merek pribadi yang hebat harus memiliki should kepribadian yang baik, tetapi didasarkan pada sosok kepribadiannya dan datang dengan segala ketidaksempurnaan.

4. Hukum kekhasan, kebutuhan personal branding yang efektif untuk ditampilkan dengan cara yang berbeda dari yang lain agar menjadi unik dan berbeda dari merek lain.

5. Hukum Visibilitas, agar diketahui brandingnya proses harus dilanjutkan dengan mempromosikan dan memasarkan dan juga menggunakan setiap kesempatan untuk menemukan dan memiliki keberuntungan untuk orang atau produk.

6. Hukum Persatuan, kehidupan pribadi sejalan dengan etika moral dan sikap yang telah ditentukan dalam proses merek pribadi.

7. The Law of Persistence, seseorang harus tetap teguh di awal Personal Branding yang sudah terbentuk, tanpa pernah ragu-ragu dan ingin berubah.

8. Hukum Niat Baik, dengan penilaian atau citra baik yang dihasilkan dari personal branding akan memberikan hasil yang lebih baik dan lama Abadi [2].

\section{Membangun Personal Branding}

Merek pribadi adalah cara Anda muncul ke dunia. Sepanjang garis ini, itu berfungsi untuk alasan

bahwa merek yang solid lebih disukai daripada merek yang tidak dipoles dan tidak menarik. Ketika individu tahu siapa Anda dan mulai membedakan Anda dengan wilayah tertentu pemahaman atau kemampuan, Anda akan baik-baik saja dalam pendekatan Anda untuk berubah menjadi individu pilihan di sudut Anda atau industry [6].

Strategi Branding harus memasukkan fitur khas antara lain : 
1. Sifat Pekerjaan: Tepat waktu, tepat, dan responsif. Ingatlah kualitas yang paling dihormati dalam perwakilan adalah kemampuan, karakter dan tugas, jadi mencoba untuk menunjukkan langkah ini.

2. Penampilan Fisik: mahir berpakaian, berdandan, dan perhiasan yang mencerminkan kepribadian Anda bagaimanapun adalah sesuai dengan bisnis tempat Anda bekerja dan perusahaan masyarakat.

3. Daya tanggap: pesan Anda, suara pesan dan bereaksi terhadap kebutuhan, terutama yang mempengaruhi kapasitas orang lain untuk melakukan pekerjaan mereka

4. Tanggung jawab: kita semua mungkin ingin selalu benar, namun Anda akan dihargai jika Anda mau bertanggung jawab ketika sesuatu tidak berjalan seperti yang diatur

5. Korespondensi dan mendengarka meskipun ada responsif Anda perlu korespondensi Anda menjadi jelas, kompak dan sadar. Ambil kesempatan yang ideal untuk mendengarkan orang lain dan mengatasi pikiran mereka.

6. Etiket Kantor: Hindari konflik atau hal yang bermasalah, terutama jika Anda bekerja di pengaturan area meja. Berhati-hatilah dengan apa yang Anda bawa makan, atau tingkah laku.

7. Merek pribadi Anda harus mencerminkan diri Anda yang sebenarnya karakter, harus didasarkan pada kualitas, kualitas, keunikan, bakat dan kemampuan

Ada beberapa aspek penting yang harus dicapai untuk personal branding :

1. Menyadari fakta bahwa orang lain mengidentifikasi sesuai dengan merek; setelah kita menentukan bagaimana, kami memutuskan strategi membangunnya serta memproyeksikan lebih banyak gambar tentang diri kita sendiri.

2. Selalu sadar tentang online kehadirannya, karena saat ini sebagian besar branding tindakan terjadi di sana;

3. Semua yang kami bagikan baik online maupun offline pasti punya tujuan, karena setiap kebersamaan informasi, status, dan gambar memililiki berkontribusi pada merek pribadi;

4. Membangun merek kuat, hal karena ini memperkuat identitas [11].

Dalam membangun sebuah personal branding melalui media sosial adalah suatu hal yang mudah dalam menumbuhkan identitas pribadi dalam reputasi, melalui media sosial adalah tempat untuk mengaktualisasi diri, karena hampir setiap oarang online dan dengan mudah mencari nama atau mencari tahu tentang kegiatan dan aktivitas seseorang.

Seseorang dapat membuat akun dan mempromosikan diri sendiri juga aktivititas untuk bisa menambah follower atau pengikut dan dapat mempersepsikan secara online di media sosial. Dunia bisnis mulai memberi lebih dan lebih penting untuk mengelola merek pribadi dan menawarkan saran strategis tentang cara membuat identitas merek pribadi yang diinginkan dengan bantuan media sosial.

Ada beberapa aspek yang perlu dipertimbangkan ketika membangun merek pribadi melalui sosial media:

1. Memiliki lebih banyak akun di berbagai sosial platform media ditunjukkan, karena mereka dapat menjangkau untuk lebih banyak orang, tetapi hanya dengan syarat untuk diperbarui secara permanen;

2. Mengembangkan pernyataan positioning yang kuat adalah sangat penting, karena ini adalah ringkasan singkat tentang siapa orang itu dan apa yang dia lakukan; kapan membuatnya, harus diperhitungkan bahwa bahkan jika pernyataan itu tentang personal branding, itu untuk orang-orang yang ingin dihubungkan oleh audience;

3. Untuk sukses dalam personal branding, seseorang harus menggunakan tampilan yang konsisten dengan

4. yang merasakan semua platform. Nama, warna, gaya dan nada yang digunakan adalah aspek branding yang harus digunakan pada semua akun yang berbeda saluran. Dengan cara ini, merek pribadi akan berjalan menjadi kenangan dan orang akan ingat lebih mudah. Ini juga membantu jika gambar profil adalah sama di berbagai profil sosial;

5. Agar mudah ditemukan, seseorang harus memposting setiap hari di jejaring sosial paling dan pastikan bahwa pesan mereknya adalah konsisten di semua dari mereka. Memiliki peranan aktif di saluran sosial penting agar untuk mendapatkan pengaruh dan pengikut, jadi signifikan aspek dalam pertumbuhan posting secara konsisten.

Dengan aktif, merek pribadi mendapat paparan dan membantu orang tersebut dalam mendapatkan posisi sebagai otoritas di ceruk masing-masing. Ketika pengikut menghubungi disarankan untuk menjawab dalam waktu 24 jam; pengikut dan mereka harapan harus selalu diperhatikan pertimbangan ketika kita menginginkan merek pribadi kita untuk sukses, oleh karena itu mereka butuh cepat respon harus dicapai. 
Terlibat dengan orang lain dengan bergabung dengan yang berbeda komunitas dan kelompok dan membuat dampak sana.

Keuntungan lain untuk mempromosikan merek pribadi di media sosial adalah bahwa kita dapat menjangkau orang-orang yang ingin kita hubungi tanpa usaha sebanyak sopan santun lainnya perlu. Selain itu, upaya dalam personal branding biasanya dibutuhkan biaya yang cukup besar untuk promosi namun dengan personal branding ini adalah cara yang efisien dalam mempromosikan diri sendiri [4].

Selain itu, sekarang hampir setiap manager akan melihat di media sosial untuk profil kemungkinan karyawan, dengan kata lain untuk personal branding. Bahkan beberapa, tergantung pekerjaannya, akan khusus membutuhkan Facebook atau sosial lainnya akun media. Ini adalah alasan untuk mengambil jaga citra dan identitas kita di media sosial, karena dapat membuka peluang karir baru atau kemitraan. Cara terbaik dalam pentingnya media sosial adalah jika konten adala sebagai bahan baka dan personal brand aalah suatu mesin, dan keduanya saling berhubungan erat dalam mempromosikan citra diri [12].

Visi dan misi dari Personal brand [5] memiliki beberapa langkah, antara lain :

Langkah 1: Kenali Merek Anda

Langkah 2: Komunikasikan Merek Anda

Langkah 3: Kontrol Ekosistem Merek Anda.

\section{KESIMPULAN DAN SARAN}

Personal branding adalah sebuah inovasi, dari sebuah personal pendekatan yang luar biasa untuk menempatkan diri di atas kertas dan memiliki representasi yang baik yang memungkinkan Anda untuk memiliki konsistensi melalui kerja dan usaha yang dituju, dengan membuat personal branding memungkinkan tinjauan yang lebih intensif pada kualitas atau atribut yang ada di media sosial.

Personal branding adalah bagian terpenting adalah mencari critical, sebuah merek akan dimulai namun tidak pernah selesai dan itu sangat penting untuk mengembangkan merek Anda dan mengikuti perkembangan terbaru. Personal branding lebih dari sekadar dari publisitas.

Ada beberapa aspek yang perlu dipertimbangkan ketika membangun merek pribadi melalui sosial media:

1. Memiliki akun di berbagai sosial platform media ditunjukkan, karena mereka dapat menjangkau lebih banyak media orang.
2. Mengembangkan pernyataan positioning yang kuat adalah sangat penting, karena ini adalah ringkasan singkat tentang siapa orang tersebut dan apa yang dia lakukan; kapan membuatnya, harus diperhitungkan hal tersebut dan untuk orang-orang terhubung oleh audience;

3. Untuk sukses dalam personal branding, seseorang harus menggunakan tampilan yang konsisten dengan yang merasakan semua platform. Seperti nama, warna, gaya dan nada yang digunakan adalah aspek branding yang harus digunakan pada semua akun namun berbeda media sosial. Dengan cara ini, personal branding akan berjalan menjadi kenangan dan orang akan ingat lebih mudah. Ini juga membantu jika gambar profil adalah sama di berbagai profil sosial;

4. Agar mudah ditemukan, seseorang harus memposting setiap hari di jejaring sosial juga pesan dari personal branding adalah konsistensi. Memiliki peranan aktif di meida sosial sangat penting agar mendapatkan pengaruh dan pengikut. Frekuensi posting yang disarankan di media sosial adalah: Facebook, Twitter, LinkedIn, Google, Pinterest, Instagram .

Membangun dan memelihara personal branding melalui media sosial. Media sosial adalah yang jalan terbaik dan cara mudah untuk suatu identitas pribadi, dalam membangun suatu reputasi dan terlibat suatu industri. Ini adalah tempat yang sempurna agar persoanal branding dapat teraktualisasi, beberapa orang sekarang online mereka akan mudah apabila mencari nama di media sosil juga tentang aktivitasnya.

\section{REFERENSI}

[1] J. Broad, The New Brand You: Your New Image Makes the Sale for You. Stick Horse Publishing.

[2] F. Elda, "Personal Branding Melalui Media Sosial, Seminar Nasional Pakar ke 1," in 2018. ISSN (P) : 2615 - 2584 Buku 2 ISSN (E, Prodi Desain Komunikasi Visual, Fakultas Seni Rupa dan Desain, Universitas Trisakti, pp. 2615 334315.

[3] Wearesocial, "No Title." [Online]. Available: https://wearesocial.com/blog/2021/01/digital2021-the-latest-insights-into-the-state-ofdigital.

[4] S. Hyder, "7 Things You Can Do To Build An Awesome Personal Brand." [Online]. Available:

http://www.forbes.com/sites/shamahyder/2014 /08/18/7-things-you-can-do-tobuild-anawesome-personal-brand/2/\#31c84eea61cc. 
[5] J. Jacobson, "You are a brand: social media managers' personal branding and 'the future audience' Ted Rogers School of Management, Ryerson University, Toronto, Canada," $J$. Prod. Brand Manag., vol. 29, no. 6.

[6] L. Kevan, Social Media Strategy-Personal Branding Tips. .

[7] A. Pawar, "The Power of Personal Branding, International Journal of Engineering and Management." Research Rajiv Gandhi Business School, University of Pune, INDI.

[8] I. Petruca, "Personal Branding Through Social Media," Univ. Assist. PhD, vol. 6, no. ue 4.

[9] Ramadhan, "Personal Branding of Anies Baswedan Through Facebook And Twitter Account: Study Of Image Grid Analysis in Banjarmasin Society Aged 17-24 Years," vol. 7. Department of Communication Science Lambung Mangkurat University.

[10] M. Yuksel and L. I. Labrecque, "'Digital buddies': parasocial interactions in social media," J. Res. Interact. Mark., vol. 10, no. 4, pp. 305-320, 2016, doi: 10.1108/JRIM-032016-0023.

[11] Sugiono, Metode Penelitian Kuatitatif kualitatif dan $R \& D$. Bandung: Alfabeta.

[12] A. R. Syahida and F. Qorib, "Personal Branding D_Kadoor untuk Menaikkan Pupolaritas Melalui Instagram, Sosial Politik Humaniora," J. Umpo Progr. Stud. Ilmu Komunikasi, Fak. Sos. Dan Ilmu Polit. Univ. Tribhuwana Tunggadewi, vol. 6, [Online]. Available:

http://journal.umpo.ac.id/index.php/aristo/. 